\title{
Logistic foundations of sustainable socio-economic development of the region in the context of decentralization
}

\author{
Alla Kasych ${ }^{1}$, Oksana Onyshchenko ${ }^{2 *}$, \\ ${ }^{1}$ Kyiv National University of Technologies and Design, Management Department, 01011, Kyiv, 2 \\ Nemirovich-Danchenko Street, Ukraine \\ ${ }^{2}$ Kremenchuk Mykhailo Ostrohradskyi National University, Department of Accounting and Finance, \\ 39600, Kremenchuk, Pershotravneva str. 20, Ukraine
}

\begin{abstract}
Incompleteness of processes of structural reformation of Ukrainian economy reveals itself on the regional level. Argument towards the utility of decentralization reform was Ukraine-Europe integration. Decentralization should be viewed as a powerful tool of governmental policy for balanced development of territorial communities. In addition, it's crucial to remember that the greatest effect will be achieved in a long term. Strategic development of united territorial communities (UTC) includes countless tasks that need to be solved as soon as possible. And organization of effective logistic activity in the region appears to be one of the ways to strengthen regional economy, to improve security level and development. The problem of ensuring stable socio-economic growth of a community is as well a logistic problem. It can be represented as a problem of optimization of flow processes of effective resource usage to achieve balanced processes of creation and consumption of resources in socio-economic system. Logistization of economic relationships on UTC level allows community to ensure better decision making of key tasks of regional management such as creation of optimal strategy to manage structural offers and material flows of social production; optimization of material, financial and informational flows of the region.
\end{abstract}

\section{Introduction}

Incompleteness of processes of structural reformation of the Ukrainian economy reveals itself on the regional level. The current administrative and territorial system in the country could not catch up with transformational processes and partially was an obstacle to the transformations in the country. It didn 't allow regions to effectively enforce it`s policies, as a result it hindered the growth of both regions and country in general. Argument towards the utility of decentralization reform was Ukraine-Europe integration. It required the appropriateness of administrative and territorial system of the country to European standards of managing regional development and local municipality. A number of studies

\footnotetext{
*Corresponding author: vikols75@ukr.net
} 
on theoretical bases of impact of decentralization on effectiveness of provision of social services in the country (Musgrave, R.A. [1], Oates, W.E. [2], Tiebout, C.A. [3]); generalization of experience of different countries in decentralization (Baldersheim, H. [4], I.P. Kovacs [5], M. Kulesza [6], I. Otola [7], A. Feltenstein, S. Iwata [8]); empirical researches on the impact of decentralization on the economic growth dynamic $(\mathrm{H}$. Baldersheim, [9], Ph. Bodman [10], J.K. Brueckner [11, 12]). Consideration of these researches is important for reformation processes in Ukraine.

Other country's experience suggests that "increased economic growth and the increase in competitiveness of the region and welfare of its population relies on how much the government is paying attention to a balanced development of the country" [13, p.6]. Regional development is mostly viewed through lens of such economical aspects as economic growth, welfare and employment (level) [14], the number of number of workplaces, people's income and labour productivity [15], as well as the overall economic welfare of the region [16, p.5]. Accounting the following aspects like social inequality, ecological situation, effectiveness of local municipality bodies, cultural diversity [17] has lead to more profound understanding of decentralization and its effects not only in economical but in social and ecological spheres.

On the current stage of development of Ukraine, territorial organization of power, when local self-government stands as a starting point in organization of management system of social development, is believed to be most optimal.

\section{Methods}

As a main method of research, we use the critical analysis and comparison of analytical reports, region development strategies and scientific publications on the issues of sustainable social and economic development of regions in the context of decentralization and also conception of logistic.

To achieve the set goals, the following general scientific and specialized methods were used: theoretical generalization, comparison and systematization - to study the essence and features of logistics activity in united territorial communities; system analysis - for determining the state and level of development of the logistics system of Ukraine and the consequences of decentralization processes in Ukraine; abstract-logical - for theoretical summarization and conclusion; graphical method - for visualization the logistic system of the territorial community as an organizational and economic mechanism.

\section{Results and Discussion}

\subsection{Decentralization reform and balanced regional growth}

Reformation of administrative and territorial system in Ukraine began in 2014. On the governmental level it was announced that the new administrative and territorial system should become the foundation of the new model of territorial management, which will be based on the practices of decentralization, social solidarity, balance of the national and community's interests, omnipresent bodies of local self-governing, ability and independency of territorial groups to manage matters of local importance [18].

Decentralization reform implied the creation of a new branch in the administrative system in Ukraine by means implementation of a new administrative and territorial unit united territorial communities (UTC). According to the data [19] from 2014 to 2019, 3,443 territorial communities were united into 878 united territorial communities; they are home to 9.0 million people ( $25.2 \%$ of the total population of Ukraine). Own revenues of local 
budgets has increased from 68.6 billion UAH in 2014 to 234.1 billion UAH in 2018. The decentralization reform changed the tax distribution formula, which affected the balance of interests between business and government. Communities are interested in attracting business to their territory, as a significant part of taxes remains in local budgets (Fig. 1).

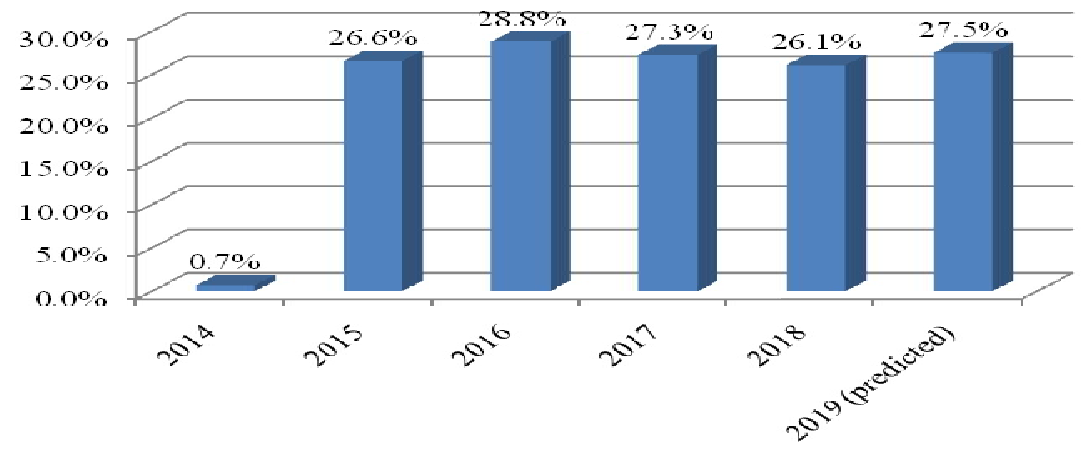

Fig. 1. Part of local taxes and fees in revenues of local budgets (2014-2019)

Source: According to the data [19].

The main purpose of the changes that are now taking place in most Ukrainian communities is to create conditions for effective development. Communities are not only united to gain more power and resources, they are consolidating their efforts to become stronger, to have resources and to be able to independently solve most of the issues that concern their residents. At the same time, the communities should also increase their level of responsibility to the business: the investor should not doubt that his funds can be used for other purposes [20]. In the 21st century understanding of the importance of balanced regional development emerges. Key priorities of European strategy 2020 are development of more effective, more ecological and more competitive economy [21, p. 8]. Decentralization should be viewed as a powerful tool of governmental policy for balanced development of territorial communities. According to A. Kasych, the mechanism of the impact of decentralization on the economic development of the country acts through the redistribution of state budget revenues in favor of the regions, the development of local infrastructure, ensuring efficient production of public goods, increasing the level of investment attractiveness and accelerating business development in the region [22].

\subsection{Logistic approach to ensure stable growth of the territorial community}

Strategic development of united territorial communities (UTC) includes countless tasks that need to be solved as soon as possible. In particular, key tasks are regarding the strengthening of economy bettering security level and balanced regional growth. However, while considering possibilities of usage of available potential, it's crucial to bear in mind the importance of logistic approach in choosing economic guides. In this aspect it is important to turn to planning, realizing and effective managing of logistic activity in the region, because many UTC territories provide many economic opportunities. Organization of effective logistic activity in the region appears to be one of the ways to strengthen regional economy, to improve security level and development. On the regional level, as the starting point of creation of new strategically guides of development of the region, it is important to consider the potential of logistic and, in particular, the ways to realize logistic activity. The main goal of logistic activity is to strengthen the regional economy, ensure its balanced growth and satisfy the needs of the customers. Logistic activity in region is there to solve such strategically problems as creation of environment to achieve competitive 
advantage and the formation of sufficient level of logistic potential.

Today conception of logistic became a foundation for innovative change in management of UTCs. So, the flows of various resources, owned by UTC (land, labor, capital, information, entrepreneurial abilities) are the object of logistic research.

While realizing logistic approach to ensure stable development of UTC it should be borne in mind that the community is an environment for people, foundation of management, means of consolidation of all spheres of social production, as well as the carrier of natural, economic, social and consumption potential. The problem of ensuring stable socio-economic growth of a community is as well logistic problem. It can be represented as a problem of optimization of flow processes of effective resource usage to achieve balanced processes of creation and consumption of resources in socio-economic system [23].

Logistization of economic relationships on UTC level allows community to ensure better decision making of key tasks of regional management such as creation of optimal strategy to manage structural offers and material flows of social production; optimization of material, financial and informational flows of the region. The execution of mechanisms of logistic management predetermines the need in creation of logistic system of UTC. Management of flow processes of resource usage is done on all stages of formation and operation of matter-energy flow, from provision of raw material resources till waste utilization. Thus, logistic system of UTC should comprise companies from production and service spheres, infrastructure objects, organizations and institutions interconnected in a process of decision making regarding the directions and ways of implementation of elements of resource flow. The logistic system of UTC should also have a system of provision of information. The logistic system of UTC is an organization mechanism of coordination of functions of resource flow management with certain characteristics that transpire in goal instructions, objects and tools of management (Fig.2).

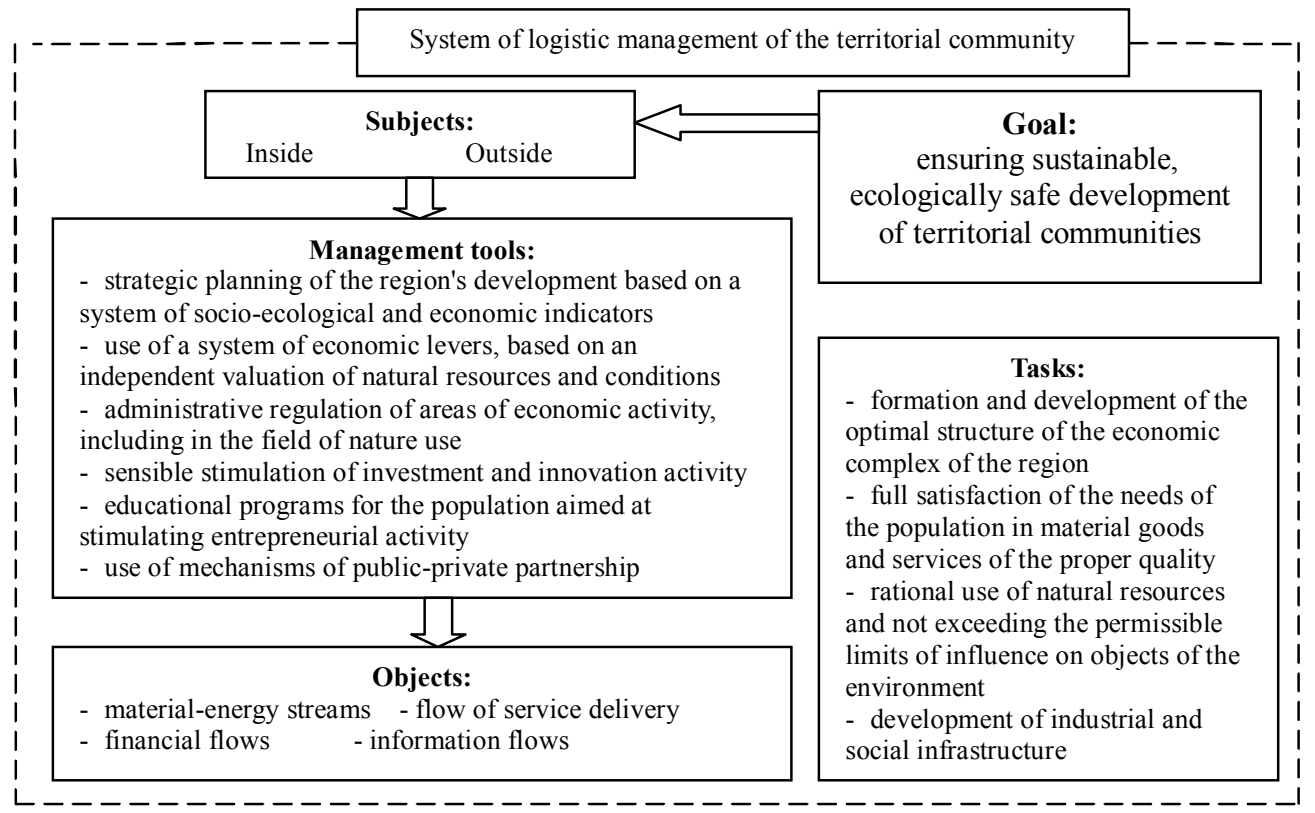

Fig. 2 Features of realization of logistic management in the regional aspect

Source: Authors

Within the framework of operational mechanism of logistic management of resource usage on UTC level, it is important to foresee, first of all, sufficient value assessment of a present natural resources potential, as well as adequate assessments of destructive economic 
activity, development of an effective tools to coordinate economic, social, and ecological interests of economic subjects and to solve existing contradictions between them.

\section{Conclusion}

Thus, implementation of logistic tool kit in regulating of resource usage processes on the level of UTC allows to create effective management approach to solve tasks regarding ensuring stable and balanced development of UTC - timely satisfaction of consumer needs in material and proper quality service, while maintaining appropriate level of quality of environmental and natural components, and minimizing social cost relatively to present organizational and economic, technical and technological conditions of management.

Further development of logistic concepts of stable socio-economic growth of regions in the context of decentralization requires the solution of the following tasks: deepening of structural and functional basis of creation of logistic systems of territorial communities; improvement of methodology used to analyze and optimize flow processes on the different hierarchy levels of management; development of structural and contextual foundations of an organizational and economic mechanism of logistic management of communities growth, as well as the development of a practical recommendations regarding its execution relatively to socio-economic conditions of a specific territorial community.

\section{References}

1. Musgrave, R.A.: The theory of public finance. McGraw-Hill, New York (1959)

2. Oates, W.E.: Fiscal Federalism. New York. http: www.jstor.org (1972)

3. Tiebout, C.A.: Pure Theory of Local Expenditures. The Journal of Political Economy. 64(5), 416-424 (1956)

4. Baldersheim, H.: Decentralisation in practice. European patterns and experiences. Publisher Ministry of Public Administration and Local Self - Government. http://www.undp.org (2011). Accesed 25 Mar 2019

5. Kovacs, I.P.: Europeanisation of Territorial Governance in Three Eastern/Central European Countries. Halduskultuur. 10, 40-57 (2009)

6. Kulesza, M.: Methods and Techniques of Managing Decentralization Reforms in CEE Countries. The Polish Experience. Public Administration Department Faculty of Law and Administration Warsaw University, Poland. http: //www.oecd.org (2002)

7. Otola, I.: Decentralization Processes of Local Government Sector in Poland. The $16^{\text {th }}$ NISPAcee Annual (2008)

8. Feltenstein, A., Iwata, S. Decentralization and macroeconomic performance in China: regional autonomy has its costs. Journal of Development Economics. 76, 481-501 (2005)

9. Baldersheim, H.: Decentralisation in practice. European patterns and experiences. Publisher Ministry of Public Administration and Local Self - Government. http: //www.undp.org (2011). Accessed 04 Apr 2019

10. Bodman, Ph., Campbell, H., Heaton, K., Hodge, A.: Fiscal Decentralisation, Macroeconomic Conditions and Economic Growth in Australia. School of Economics, The University of Queensland, Macroeconomics Research Group (2009)

11. Brueckner, J.K.: Fiscal Decentralization with Distortionary Taxation: Tiebout vs. Tax Competition International Tax and Public Finance. 11, 133-153 (2004)

12. Brueckner, J.K.: Fiscal federalism and economic growth. Journal of Public Economics. 90(10), 2107-2120 (2006)

13. Regionalnij rozvitok ta derzhavna regionalna politika $\mathrm{v}$ Ukrayini: stan i perspektivi zmin u konteksti globalnih viklikiv ta yevropejskih standartiv politiki. 
https://bit.ly/2HIeWjF (2019). Accessed 14 Apr 2019

14. Armstrong, H., Taylor, J.: Regional Economics and Policy. Oxford, Blackwell (2000)

15. Storper, M.: The Regional World: Territorial Develop ment in a Global Economy. Guilford, London (1997)

16. Beer, A., Haughton, G., Maude, A.: Developing Locally: An International Comparison of Local and Regional Economic Development. Policy Press, Bristol (2003)

17. Haughton, G., Counsell, D., Haughton, G.: Regions, Spatial Strategies and Sustainable Development. Routledge and Regional Studies Association, London (2004)

18. Pavlyuk, A.P., Olijnik, D.I., Batalov, O.A., Dacko, O.I., Valyushko, I.V., Barvickij, S.Yu.: Teritorialna gromada yak bazova lanka administrativno-teritorialnogo ustroyu Ukrayini: problemi ta perspektivi reformuvannya. Analitichna dopovid. NISD, Kyiv (2016) 19. Decentralization of power. https://storage.decentralization.gov.ua/ uploads/ library/ file/ 378/10.02.2019_ukr.pdf(2018). Accessed 23 May 2019

20. Pochtovyuk, A., Semenikhina, V., Onyshchenko, O. and Ruban, B.: The formation and development of social responsibility of business: Ukrainian experience in a context of decentralization. SHS Web of Conferences 61, 01018 (2019). doi: $10.1051 /$ shsconf $/ 20196101018$

21. Europe 2020: A European strategy for smart, sustainable and inclusive growth. http://ec.europa.eu/eu2020/pdf (2010). Accessed 30 May 2019

22. Kasych, A.O.: Theoretical aspects of decentralization processes impact on economic development of the country. Actual Problems of Economics. 182 (8), 16-21 (2016)

23. Mishenin, Ye.V., Koblyanska, I.I: logistichni osnovi stalogo socialno-ekonomichnogo rozvitku region. Visnik Sumskogo nacionalnogo agrarnogo universitetu. 5(60), 3-7 (2014) 